\title{
19. PALEOCENE TO RECENT PLANKTONIC MICROFOSSIL DISTRIBUTION IN THE MARINE AND LAND AREAS OF THE CARIBBEAN
}

\author{
John B. Saunders, Texaco Trinidad Inc., Pointe-a-Pierre, Trinidad \\ Fred M. Beaudry and William W. Hay, Rosenstiel School of Marine and Atmospheric Sciences, Miami, Florida \\ Hans M. Bolli and Fred Rögl, Geology Department, Swiss Federal Institute of Technology, Zürich, Switzerland \\ William R. Riedel and Annika Sanfilippo, Scripps Institute of Oceanography, La Jolla, California \\ and \\ Isabella Premoli Silva, University of Milan, Milan, Italy
}

\section{INTRODUCTION}

The three charts that accompany this paper represent an attempt to show the present state of our knowledge concerning the distribution of the major planktonic microfossil groups in the Caribbean region from Paleocene to Recent. The publication of the DSDP Leg 15 results seems a good time to take stock and to attempt to relate the major groups-foraminifera, nannofossils, and Radiolariato each other with as great an accuracy as possible.

The ideal situation, with completely cored and suitably fossiliferous sections spanning the whole time interval, does not exist and, therefore, we have had to use various approaches in our attempts to complete the charts.

Available pertinent stratigraphic information on the calcareous microfossil groups from the Greater Antilles, the Lesser Antilles, and northern South America has been incorporated.

The four columns in the right-hand portion of each chart give an indication as to the representation of the appropriate fauna or flora at the various zonal levels. It must be stressed that the absence of a particular fauna or flora throughout the region does not necessarily mean this interval is missing or was never deposited in a deep marine facies, but rather, that up to the present time, it has not been found for any of a variety of reasons. As far as DSDP drilling is concerned, the zone may be of very short duration and may have been missed due to small gaps in sampling; it may be one of widespread dissolution of tests or; if it is in the older part of the column, it may have been only infrequently penetrated.

The columns are grouped into marine and land areas since results from oceanic cores are often different fro those from land-based sections, either surface or subsurface. Columns 1 and 3 indicate whether a fauna or flora is known at all in the region and, if so, in what state of preservation (i.e., Good, Medium, or Poor preservation). Columns 2 and 4 indicate whether the fauna or flora is known to be widely present (W) through the region or has so far been found only at a limited (L) number of places.

The absolute age values shown on the charts are from Rögl and Bolli (this volume) for the Pleistocene and from Berggren (1972) for the remainder of the time interval.

\section{PLANKTONIC FORAMINIFERA}

At all stratigraphic levels, where possible, the results from Legs 4 and 15 have been utilized in making up the chart. The major references are Rögl and Bolli, Bolli and Premoli Silva, and Premoli Silva and Bolli (this volume) and Bolli (1970) in the Leg 4 Initial Report. The time periods for which the DSDP site results have proved of most value are Pleistocene, Pliocene, Early Eocene, and Paleocene.

For the later Pleistocene and overlying Holocene, the results from Site 147 in the Cariaco Basin have made possible the erection of a new zonation which is continued downwards to the base of the Pleistocene using Sites 148 and 154 of Leg 15 and Sites 29, 30, and 31 of Leg 4.

Data for events within the Pliocene have come from Sites 148 and 154 of Leg 15 and Sites 29, 30, and 31 of Leg 4.

Site 30 has been used for the interval Middle Miocene down to the top of the Early Miocene.

Refinement of the zonation of the Early Eocene has been made possible from the results of Sites 146, 150,151, 152 , and 153 .

The best Paleocene section, though still incomplete, is the one documented from Site 152. Additional Paleocene data came from Sites 152 and 153. From the latter, it has been possible to recognize the first known occurrence of the Globigerina eugubina Zone in the Caribbean area.

The late Early to uppermost Eocene in the Caribbean marine areas pose a particular problem for comparison of the microfossil groups because good calcareous faunas and floras have not yet been found in the basins. For this reason, it has not been possible to equate the radiolarian zonation with the planktonic foraminiferal zonation which is used as a standard for the charts. It must be made clear that Cores 31 through 41 of Site 149 , with their siliceous microfaunal assemblages, have been placed against the Globorotalia cerroazulensis s. I. Zone to Hantkenina aragonensis Zone interval in a rather arbitrary fashion.

Much work has been done on planktonic foraminiferal faunas from land sections in the Caribbean area. Major use was made of the following papers during compilation: Bolli (1957a), Blow (1959), Bolli (1964), Bolli and Bermudez (1965), Bolli (1966), Blow (1967), and Bermudez and Bolli (1969) for the Pliocene to Oligocene; and Bolli (1957b, 1957c), Blow (1969), Proto Decima and Bolli (1970), and Tourmarkine and Bolli (1970) for the Eocene and Paleocene.

\section{NANNOFOSSILS}

In preparing the composite range chart presented here, data from all available sources concerning the distribution 
of calcareous nannofossils in the Caribbean region have been used. Calcareous nannofossils were first recorded in this part of the world by Jukes-Browne and Harrison (1892), who figured specimens from the Oceanic Formation of Barbados. Subsequent accounts of coccoliths and related fossils from the Eocene and Oligocene of Barbados have been presented, with range charts, by Hay in Hay et al. (1967) and Roth (1970). Samples from Trinidad have been studied by a number of workers, and many species have been described (Bramlette and Riedel, 1954; Hay et al., 1967; Bramlette and Wilcoxon, 1967, Gartner, 1967; Hay and Mohler, 1967; Bukry and Bramlette, 1969; Roth, 1970; Bukry, 1971; and Bukry and Percival, 1971). Of these, only Hay et al. (1967) and Bramlette and Wilcoxon (1967) presented detailed range charts, and these were usually limited to a single sample per planktonic foraminiferal zone. Although a large number of species have been recognized in samples from Trinidad, refined stratigraphic analysis of their ranges has not been made because of the lack of material from additional levels.

Coccoliths and related calcareous nannofossils from the Caribbean Sea proper have been described by Cohen (1964). The distribution of calcareous nannofossils in drilled cores from this area has been described by Bolli et al. (1968), Hay and Boudreaux (1968), Boudreaux and Hay (1969), Hay (1970), Bukry (1970), and, in this volume, by Hay and Beaudry and by Bukry. Range charts particularly important in constructing the composite presented here have been those in Boudreaux and Hay (1960), Hay (1970), and Hay and Beaudry (1973).

The assemblages from the Caribbean Sea proper, the area for which the most detailed range charts are available, lack a number of species present in Trinidad. Only those species are plotted here for which information more accurate or precise than that presented by Hay et al. (1967), Bramlette and Wilcoxon (1967), and Roth (1970) has become available. Wherever possible, the ranges have been compared with those of planktonic foraminifera.

The Late Pliocene through Holocene ranges are based on information from Sites 147, 148, 149, and 154 of Leg 15; Sites 29, 30, and 31 of Leg 4; and on the Submarex cores.

The Early Pliocene has not been recovered in continuous fossiliferous sediments at any of the Caribbean sites investigated, but it is known to the southeast from Site 25 of Leg 4 on the North Brazilian Ridge, and to the north from Site 3 of Leg 1 in the Gulf of Mexico. The sequence is listed here for convenience and to show its relation to the planktonic foraminiferal zonation.

The data on Miocene ranges are mostly from Sites 149, 150,151 , and 153 of Leg 15 and Site 29 of Leg 4.

Only the middle and late Oligocene are represented by sediments with good assemblages of calcareous nannofossils in the Caribbean Sea. The most useful sequences are from Sites 149, 151, and 153 of Leg 15 and Site 31 of Leg 4.

The middle and late Eocene are generally represented by radiolarian-rich sediments with relatively sparse assemblages of calcareous fossils. Only the more resistant species of calcareous nannofossils occur, and planktonic foraminifera present are generally inadequate to permit assignment of the samples to specific zones. The ranges of species for these intervals have been plotted by using data from Site
149. The ranges of calcareous nannoplankton and radiolarians can be correlated because the two groups of fossils occur in the same cores, but their relation to planktonic foraminifers is questionable and approximate at best.

The Lower Eocene is also generally poor, with only the basal interval represented by calcareous-nannofossil-rich sediments. In plotting ranges, data from Sites 146, 151, and 152 were useful.

The Paleocene is generally incomplete in the cored sections. The middle and late Paleocene are best represented by, and useful data derived from, Sites 146, 151, 152 , and 153.

The distribution of calcareous nannofossils in Cretaceous sediments of the Caribbean is presented in the chapter by Hay and Beaudry in this volume. The assemblages are commonly limited to long-ranging species, and no attempt has been made to compare ranges with those of planktonic foraminifera or radiolarians.

\section{RADIOLARIA}

Although in the case of the calcareous microfossil groups discussed above a considerable amount of biostratigraphic information is available from land-based sequences in the Caribbean as well as from DSDP cores, it is predominantly from DSDP materials that such information is available on the radiolarians. The small amount of radiolarian information available from the Cenozoic of Barbados, Trinidad, and Cubs is summarized by Riedel and Sanfilippo (1971).

DSDP Leg 4 collected a useful Caribbean Middle Eocene radiolarian sequence at Site 29 (Riedel and Sanfilippo, 1970), and on Leg 10, in the Gulf of Mexico, a similar sequence was again sampled, together with younger radiolarian material extending upward to Early Miocene, and older material permitting extension of the zonation downward through Early Eocene and with intermittent samples of Paleocene (Foreman, 1973; Sanfilippo and Riedel, 1973). Radiolarian materials from Leg 15 provide Caribbean equivalents of the sequence recovered in the Gulf of Mexico and permit species ranges to be determined in parallel with those of calcareous microfossils (except through the Middle and Late Eocene, where foraminifera did not occur). Although more numerous Paleocene samples were obtained on Leg 15 than on previous legs of DSDP, the recovery was intermittent and radiolarian preservation not adequate for detailed biostratigraphy.

The range chart presented is based on species ranges observed in Cores 151-4 and -5 (for early Middle and Early Miocene), Cores 149-23 to -30 (for Middle and Late Oligocene), Cores $153-7$ and $149-31$ to -43 (for Middle and Early Oligocene through the Eocene) and Cores 152-1 to -9 (from early Early Eocene to Middle Paleocene). Some other sites provide evidence not entirely consistent with the ranges as plotted here (see Table 9 of the radiolarian chapter in this volume), but such additional evidence is not taken into consideration in drawing the range chart since it seems important to be able to specify which sediment sequences constitute its basis.

Late Neogene radiolarians of the Caribbean remain unknown since assemblages younger than the Middle Miocene Cannartus petterssoni Zone do not occur in either 
land-based localities or deep-sea drillings in this region (Riedel and Sanfilippo, 1970, 1971; Sanfilippo and Riedel, 1973).

\section{REFERENCES}

Berggren, W. A., 1972. A Cenozoic time-scale-some implications for regional geology and paleobiogeography: Lethaia, v. 5, p. 195-215.

Bermudez, P. J. and Bolli, H. M., 1969. Consideraciones sobre los sedimentos del Mioceno medio al reciente de las costas central y oriental de Venezuela. Tercera parte. Low foraminiferos planctonicos: Caracas Geol. Bol., v. 10 , no. 20 , p. $137-223$.

Blow, W. H., 1959. Age, correlation and biostratigraphy of the upper Tucuyo (San Lorenzo) and Pozon formations, eastern Falcon, Venezuela: Am. Pal. Bull., v. 39, no. 178 , p. $59-251$.

1969. Late Middle Eocene to Recent planktonic foraminiferal biostratigraphy: Internat. Conf. Planktonic Microfossils, Geneva, 1967. Proc. Brill, E. J. (Ed.), p. 199-422.

Bolli, H. M., 1957a. Planktonic Foraminifera from Oligocene-Miocene Cipero and Lengua Formations of Trinidad, B.W.I: U.S. Nat. Mus. Bull., v. 215, p. 97-123. 1957b. Planktonic Foraminifera from the Eocene Navet and San Fernando Formations of Trinidad, B.W.I: U.S. Nat. Mus. Bull. v. 215, p. 155-172.

1957c. The genera Globigerina and Globorotalia in the Paleocene-lower Eocene Lizard Springs Formation of Trinidad, B.W.I: U.S. Nat. Mus. Bull. v. 215, p. 61-81. 1964. Observations on the stratigraphic distribution of some warm water planktonic Foraminifera in the young Miocene to Recent: Ecol. geol. Helv., v. 57, no. 2, p. 541-552.

1966. Zonation of Cretaceous to Pliocene marine sediments based on planktonic Foraminifera: Bol. Informativo, v. 9 , no. 1, p. 3-32.

1970. The Foraminifera of Sites 23-31, Leg 4: Initial Reports of the Deep Sea Drilling Project, Volume IV. Washington (U.S. Government Printing Office), p. 577-643.

Bolli, H. M. and Bermudez, P. J., 1965. Zonation based on planktonic Foraminifera of Middle Miocene to Pliocene warm-water sediments: Asoc. Venez. Geol. Min. Petrol., Bol., v. 8, no. 5, p. 119-149.

Bolli, H. M., Boudreaux, J. E., Emiliani, C., Hay, W. W., Hurley, R. J., and Jones, J. I., 1968. Biostratigraphy and paleotemperatures of a section cored on the Nicaragua Rise, Caribbean Sea: Geol. Soc. Am. Bull. v. 79, p. $459-470$.

Boudreaux, J. E. and Hay, W. W., 1969. Calcareous nannoplankton and biostratigraphy of the late PliocenePleistocene-Recent sediments in the Submarex cores: Riv. Espan. Micropaleontol., v. 1, p. 249-292.

Bramlette, M. N. and Riedel, W. R., 1954. Stratigraphic value of discoasters and some other microfossils related to Recent Coccolithophores: J. Paleontol., v. 28, p. $385-403$.

Bramlette, M. N. and Wilcoxon, J. A., 1967. Middle Tertiary calcareous nannoplankton of the Cipero section, Trinidad, W. I: Tulane Studies Geol., v. 5, p. 93-131.

Bukry, D., 1970. Coccolith age determinations, Leg 4, Deep Sea Drilling Project: Initial Reports of the Deep Sea
Drilling Project, Volume IV. Washington (U.S. Government Printing Office), p. 375-381.

1971. Discoaster evolutionary trends: Micropaleontology, v. 17, p. 43-52.

Bukry, D. and Bramlette, M. N., 1969. Some new and stratigraphically useful calcareous nannofossils of the Cenozoic: Tulane Studies Geol., v. 7, p. 131-142.

Bukry, D. and Percival, S. F., Jr., 1971. New Tertiary calcareous nannofossils: Tulane Studies Geol., v. 8, p. 123-146.

Cohen, C. L. D., 1964. Coccolithophorids from two Caribbean deep-sea cores: Micropaleontology, v. 10, p. 231-250.

Foreman, Helen, 1973. Radiolaria of Leg 10 with systematics and ranges for the families Amphipyndacidae, and Theoperidae: Initial Reports of the Deep Sea Drilling Project, Volume X. Washington (U.S. Government Printing Office), p. 407-474.

Hay, W. W., 1970. Calcareous nannofossils from cores recovered on Leg 4: Initial Reports of the Deep Sea Drilling Project, Volume IV. Washington (U.S. Government Printing Office), p. 455-501.

Hay, W. W. and Boudreaux, J. E., 1968. Calcareous nannofossils in the Submarex cores, Nicaragua Rise, Caribbean Sea; Le Castella, Calabria; and the age of the Pliocene-Pleistocene boundary: Gior. Geol., v. 35, p. 143-151.

Hay, W. W. and Mohler, H. P., 1967. Calcareous nannoplankton from early Tertiary rocks at Pont Labau, France, and Paleocene-Early Eocene correlations: J. Paleontol., v. 41, p. 1505-1541.

Hay, W. W., Mohler, H. P., Roth, P. H., Schmidt, R. R., and Boudreaux, J. E., 1967. Calcareous nannoplankton zonation of the Cenozoic of the Gulf Coast and CaribbeanAntillean area and transoceanic correlation: Gulf Coast Assoc. Geol. Soc. Trans. v. 17, p. 428-480.

Jukes-Browne, A. J. and Harrison, J. B., 1892. The geology of Barbados. Part II. The Oceanic deposits: Geol. Soc. London, Quart. J., v. 48, p. 170-226.

Proto Decima, F. and Bolli, H. M., 1970. Evolution and variability of Orbulinoides beckmanni (Saito). Ecol. geol. Helv., v. 63, no. 3, p. 883-905.

Riedel, W. R. and Sanfilippo, Annika, 1970. Radiolaria, Leg 4, Deep Sea Drilling Project: Initial Reports of the Deep Sea Drilling Project, Volume IV. Washington (U.S. Government Printing Office), p. 503-575. 1971. Cenozoic Radiolaria from the western tropical Pacific, Leg 7: Reports of the Deep Sea Drilling Project, Vol. VII. Washington (U.S. Government Printing Office), p. 1529-1672.

Roth, P. H., 1970. Oligocene calcareous nannoplankton biostratigraphy: Ecol. geol. helv., v. 63, p. 799-881.

Sanfilippo, Annika and Riedel, W. R., 1973. Cenozoic Radiolaria (exclusive of Theoperids, Astostrobiids and Amphipyndacids) from the Gulf of Mexico, Leg 10: Inaitial Reports of the Deep Sea Drilling Project, Vol. X. Washington (U.S. Government Printing Office), p. 475-611.

Tourmarkine, M. and Bolli, H. M., 1970. Evolution de Globorotalia cerroazulensis (Cole) dans l'Eocene Moyen et Superieur de Possagno (Italie): Rev. Micropaleontol., v. 13 , no. 3 , p. $131-145$. 